\section{6 OPEN ACCESS}

SHORT REPORT

\title{
Cerebral microbleeds and the risk of intracerebral haemorrhage after thrombolysis for acute ischaemic stroke: systematic review and meta-analysis
}

\author{
Andreas Charidimou, ${ }^{1}$ Puneet Kakar, ${ }^{2}$ Zoe Fox, ${ }^{3,4}$ David J Werring ${ }^{1}$
}

\begin{abstract}
- An additional supplementary figure and supplementary tables 1 to 3 are published online only. To view these files please visit the journal online (http://dx.doi.org/10.1136/jnnp2012-303379).

${ }^{1}$ Stroke Research Group, Department of Brain Repair and Rehabilitation, UCL Institute of Neurology and The National Hospital for Neurology and Neurosurgery, Queen Square, London WC1N 3BG, UK

${ }^{2}$ Department of Stroke Medicine, Imperial College Healthcare, NHS Trust, London, UK

${ }^{3}$ Biomedical Research Centre, UCL, London, UK

${ }^{4}$ Education Unit, UCL Institute of Neurology, London, UK
\end{abstract}

Correspondence to Dr David J Werring. Stroke Research Group, Department of Brain Repair and Rehabilitation, UCL Institute of Neurology and National Hospital for Neurology and Neurosurgery, Box 6, Queen Square, London WC1N 3BG, UK;

d.werring@ucl.ac.uk

Received 3 June 2012 Revised 13 August 2012 Accepted 28 August 2012 Published Online First 28 September 2012

\section{ABSTRACT}

Background Intracerebral haemorrhage (ICH) remains the most devastating yet unpredictable complication of intravenous thrombolysis for acute ischaemic stroke. We performed a systematic review and meta-analysis, to assess whether the presence of cerebral microbleeds (CMBs) on prethrombolysis MRI scans is associated with an increased risk of $\mathrm{ICH}$.

Methods We searched PubMed for studies assessing $\mathrm{ICH}$ risk in patients with acute ischaemic stroke treated with thrombolysis, in relation to the presence of pretreatment CMBs.

Results We identified five studies including 790 patients and pooled data in a meta-analysis. The CMB $(+)$ versus CMB (-) groups were not significantly different in age, gender or stroke severity. The overall prevalence of CMBs was 135/790 (17.1\%). Amongst patients with CMBs, 10/135 (7.4\%) experienced a symptomatic ICH after thrombolysis, compared to 29/655 (4.4\%) patients without CMBs. The pooled relative risk of $\mathrm{ICH}$ was 1.90 (95\% Cl 0.92 to 3.93; $p=0.082$ ).

Conclusions The available evidence does not demonstrate a statistically significant increased risk of symptomatic ICH after thrombolysis for ischaemic stroke in patients with CMBs. However, in view of the methodological limitations of the studies included, the clinical relevance of any potential hazard associated with CMBs remains uncertain. Further studies are warranted to evaluate whether the risk of $\mathrm{ICH}$ might outweigh the benefit of thrombolysis, especially in patients with multiple lobar CMBs suggestive of cerebral amyloid angiopathy.

\section{INTRODUCTION}

Intravenous thrombolysis is the only effective licensed treatment for acute ischaemic stroke. However, the improved outcomes overall come at the cost of a small increase in risk of intracerebral haemorrhage $(\mathrm{ICH})$, the most devastating yet unpredictable complication. ${ }^{1}$ Symptomatic ICH occurs in about $2.4-10 \%$ of cases within $24-36 \mathrm{~h}$ of thrombolysis (depending on the definition used), and may be disabling. ${ }^{12}$ Identifying patients at higher risk for $\mathrm{ICH}$ following thrombolysis is thus an urgent clinical priority: a reliable and safe way to do this could increase the overall safety profile of this widely used treatment. Markers of increased risk include increasing age, early ischaemic CT changes, high blood pressure, hyperglycaemia, clinical stroke severity as assessed by the National Institute of Health Stroke Scale score on admission, large baseline diffusion lesion volume and cerebral white matter changes (leukoaraiosis), but there is currently no reliable way to predict severe $\mathrm{ICH}^{1}{ }^{1}$ Cerebral microbleeds $(\mathrm{CMBs})$ - small perivascular haemorrhages seen as welldemarcated, hypointense, rounded lesions on MRI sequences sensitive to magnetic susceptibility-are a marker of haemorrhage-prone microangiopathies (mainly hypertensive arteriopathy or cerebral amyloid angiopathy (CAA)). Because CMBs are a rather specific marker for previous bleeding from pathologically fragile cerebral small vessels, ${ }^{3}$ they might help to identify a subpopulation of patients at high risk of clinically significant $\mathrm{ICH}^{4}$ Previous studies have given conflicting results regarding the possible risk of ICH after thrombolysis in individuals with CMBs. ${ }^{5}$ We therefore performed a systematic review and meta-analysis to assess the evidence whether the presence of CMBs on prethrombolysis MRI scans is associated with an increased risk of ICH.

\section{METHODS}

\section{Search strategy and selection criteria}

We searched PubMed between 1 January 1995 and 1 February 2012 using the following search terms: 'microbleed(s)', or 'micro(-)h(a)emorrhage(s)', or 'gradient-echo' in association with 'thromboly*' or 'tPA', or 'tissue plasminogen activator'. Reference lists from all included articles and the authors' own files were also searched for relevant publications. Papers not published in English and case reports were excluded. Two authors (AC and PK) identified potentially relevant studies, resolving any uncertainties with a third author (DJW).

\section{Eligibility criteria}

Studies were eligible for inclusion if they had assessed ICH risk in patients with acute ischaemic stroke treated with thrombolysis, and quantified this risk in relation to the presence of $\mathrm{CMBs}$ on pretreatment MRI scans.

\section{Data extraction}

Two authors (AC and PK) went through all articles selected as potentially relevant and extracted data independently. We extracted information on type of study, number and nature of participants (including mean age and sex), MRI parameters, duration of follow-up, number of participants with at least one $\mathrm{CMB}$ and number of participants with the outcome event (symptomatic ICH defined according to standard criteria). Consensus was reached by discussion. 
Studies were critically appraised against a checklist of key quality indicators with reference to the STROBE (STrengthening the Reporting of OBservational studies in Epidemiology) statement and the ideal characteristics for a study of $\mathrm{CMBs}^{7}$ (see online supplementary table S1) (Clearly defined CMB criteria, clear definition of the study population, standardised MRI parameters, clearly defined ICH criteria, awareness of $>2 \mathrm{CMB}$ mimics, standardised rating scale or trained observer with reported inter-rater/ intra-rater agreement, data on $\mathrm{CMB}$ distribution and adjustment for other ICH risk factors).

\section{Meta-analysis}

We used a fixed effects model to calculate the pooled relative risk (RR) of symptomatic ICH in patients with versus without $\mathrm{CMBs}$, where weights were calculated using the inverse variance method. We assessed heterogeneity using I-squared and $\mathrm{x}$-squared statistics and through visual inspection of the forest plot. We explored publication bias with the funnel plot. Meta-analyses were performed using Stata 11.2 (StataCorp LP, Texas, USA). We prepared this report with reference to MOOSE (meta-analyses of observational studies) guidelines. ${ }^{8}$

\section{RESULTS}

We identified 62 articles in our initial search of PubMed; five studies including a total of 790 patients (135 with CMBs) met our inclusion criteria, and were pooled in a meta-analysis. ${ }^{5} 6$ 9-11 One study was excluded ${ }^{12}$ because of overlap with a previously published cohort. ${ }^{6}$ A summary of the characteristics of included studies is provided in table 1 and online supplementary tables S2 and S3. There was no evidence of publication bias in the funnel plot (see online supplementary figure $\mathrm{S} 1$ ). The $\mathrm{CMB}(+)$ versus $\mathrm{CMB}(-)$ groups were not significantly different in age, gender or stroke severity, except that in one study higher age was associated with CMBs. ${ }^{6}$ The overall prevalence of $\mathrm{CMBs}$ on pretreatment MRI scans was $17.1 \%$. Amongst patients with CMBs, 10/135 (7.4\%) experienced a symptomatic ICH after thrombolysis, compared to $29 / 655(4.4 \%)$ patients without CMBs; the pooled RR of ICH was 1.90 (95\% CI 0.92 to 3.93 ; $p=0.082$ ) (figure 1). The results were consistent from study to study $(p=0.800)$.

\section{DISCUSSION}

Our systematic review and meta-analysis in nearly 800 patients with acute ischaemic stroke shows that the presence of CMBs on a pretreatment MRI scan is not associated with a statistically significant increased risk of symptomatic ICH following thrombolysis. However, there was a trend for a higher ICH risk in those patients with CMBs (pooled RR 1.90; 95\% CI 0.92 to 3.93; $\mathrm{p}=0.082$ ).

With the introduction of $\mathrm{T} 2 *$-weighted gradient-recalled echo (T2*-GRE) and susceptibility-weighted imaging, CMBs are increasingly detected in patients with acute ischaemic stroke. ${ }^{4}$ Evidence suggests that $\mathrm{CMBs}$ are a prognostic marker for future ICH risk after stroke. ${ }^{13}{ }^{14}$ However, only five studies have reported on the risk of ICH following thrombolysis for acute ischaemic stroke in patients screened for CMBs. ${ }^{5}$ 9-11 Recent studies indicate that the rate of symptomatic thrombolysis-related ICH is increased in the presence of moderate-to-severe leukoaraiosis, implying that cerebral small vessel is a risk factor for $\mathrm{ICH}^{15}{ }^{16}$ However, leukoaraiosis lacks pathological specificity, by contrast with CMBs, which appear to specifically reflect small areas of haemorrhage from vessels affected by bleeding-prone arteriopathies (mainly hypertensive arteriopathy or CAA). ${ }^{3}$
Several methodological aspects of the included studies deserve consideration. Importantly, most had a small sample size; only the multicentre BRASIL (bleeding risk analysis in stroke imaging before thrombolysis) study $(n=570)$ had more than 100 patients, and hence dominated our meta-analysis. ${ }^{6}$ Furthermore, all studies are subject to selection bias since not all acute stroke patients undergo $\mathrm{T} 2{ }^{*}$-GRE, and such patients were excluded.

Imaging parameters varied between studies, which could affect the prevalence of CMBs. ${ }^{4}{ }^{17}$ In some centres in the BRASIL study ${ }^{6}$ a small proportion of stroke patients had CMBs, and only six patients had five or more CMBs, suggesting that some MRI protocols were not optimal to detect CMBs, which are typically found in about $20-30 \%$ of ischaemic stroke patients; ${ }^{7}$ Moreover, the studies did not use standardised rating scales for $\mathrm{CMBs}$, and did not report on $\mathrm{ICH}$ risk in relation to $\mathrm{CMB}$ number and anatomical location.

Although the outcome definitions for ICH were not standardised among the studies included, all included ICH associated with clinical deterioration and thus likely to be clinically relevant.

A range of different thrombolysis protocols were used (table 1 and online supplementary table S3): for example Kim et al included both intravenous and intra-arterial thrombolysis, but found no statistically significant difference between the groups in haemorrhagic complications. ${ }^{9}$ The study by Derex et a ${ }^{11}$ included two drug doses but found no significant influence of dose on the risk of ICH.

Some studies did not provide full details of some baseline characteristics likely to be important for thrombolysis-related $\mathrm{ICH}$, for example, hyperglycaemia, hypertension, prior use of antiplatelet and anticoagulant medications or recurrent stroke.

$\mathrm{CMBs}$ might increase the risk of thrombolysis-related $\mathrm{ICH}$ either as the direct source of the $\mathrm{ICH}$, or as a general marker of small vessel fragility. About $20 \%$ of patients with acute ischaemic stroke develop new CMBs in the first few days, ${ }^{18}$ suggesting an active, diffuse microangiopathy, which with the administration of thrombolysis could cause symptomatic ICH. Since most new $C M B$ s in this study ${ }^{18}$ developed in patients with baseline CMBs, prethrombolysis CMBs may be a marker for patients at most risk of symptomatic ICH. However, the free circulating plasma half-life of alteplase is very short (between 4-6 min), and that the exact mechanisms of ICH post-thrombolysis remain uncertain.

Deep CMBs in the basal ganglia and brainstem are most likely related to hypertensive arteriopathy, while multiple strictly lobar $\mathrm{CMBs}$ are likely to reflect CAA. ${ }^{4}$ CAA may be a particular risk factor for post-thrombolysis ICHs, which are often lobar, multiple and occur remote from the infarct in around $20 \%$ of patients. ${ }^{19}$ Pathological studies also support a role of pre-existing CAA: one study reported that $70 \%$ of patients with thrombolysis-related ICH had autopsy-proven CAA compared to $22 \%$ of unselected ICH patients of similar age. $^{20}$ Finally, an increased risk of ICH was associated with intravenous thrombolysis in CAA transgenic mice. ${ }^{21}$ Strictly lobar $\mathrm{CMBs}$ form an important part of recent diagnostic criteria for $\mathrm{CAA},{ }^{22}$ so may be of particular prognostic value for $\mathrm{ICH}$, but this has not been addressed by previous studies.

\section{CONCLUSIONS}

Our analysis suggests a trend of increased risk of symptomatic ICH after thrombolysis for ischaemic stroke if CMBs are present on pretreatment MRI. Although the risk was not statistically significant at the 0.05 level, the data do not rule out a possible clinically important increased hazard for thrombolysis in 
Table 1 Characteristics of included studies

\begin{tabular}{|c|c|c|c|c|c|c|c|c|c|c|c|c|c|}
\hline \multirow[b]{2}{*}{ Study } & \multirow[b]{2}{*}{ Study design } & \multirow[b]{2}{*}{$\begin{array}{l}\text { Patient } \\
\text { number } \\
\text { (\% men) }\end{array}$} & \multirow[b]{2}{*}{$\begin{array}{l}\text { Mean age } \\
\text { (years) }\end{array}$} & \multirow[b]{2}{*}{$\begin{array}{l}\text { Initial stroke } \\
\text { severity } \\
\text { (NIHSS) }\end{array}$} & \multicolumn{3}{|c|}{ T2*-GRE MRI parameters } & \multirow[b]{2}{*}{$\begin{array}{l}\text { CMBs } \\
\text { prevalence } \\
\text { (95\% CI) }\end{array}$} & \multirow[b]{2}{*}{$\begin{array}{l}\text { Differences } \\
\text { CMBs }(+) \text { versus } \\
\text { CMBs (-) groups }\end{array}$} & \multirow{2}{*}{$\begin{array}{l}\text { Thrombolysis } \\
\text { (see online } \\
\text { supplementary } \\
\text { table S3) }\end{array}$} & \multirow[b]{2}{*}{$\begin{array}{l}\text { FU } \\
\text { time } \\
\text { (days) }\end{array}$} & \multirow[b]{2}{*}{$\begin{array}{l}\text { Symptomatic } \\
\text { ICH definition }\end{array}$} & \multirow[b]{2}{*}{$\begin{array}{l}\text { Other risk factors for } \\
\text { thrombolysis-related } \\
\text { ICH accounted for }\end{array}$} \\
\hline & & & & & $\begin{array}{l}\text { Field } \\
\text { strength } \\
\text { (Tesla) }\end{array}$ & $\begin{array}{l}\text { Echo time } \\
\text { (ms) }\end{array}$ & $\begin{array}{l}\text { Section } \\
\text { thickness } \\
(\mathrm{mm})\end{array}$ & & & & & & \\
\hline $\begin{array}{l}\text { Fiehler } \\
2007\end{array}$ & $\begin{array}{l}\text { Prospective, } \\
\text { multicentre (13) }\end{array}$ & $570(-)$ & $69(59-77)^{*}$ & 13 (IOR:8-17) & - & $14-49$ & $5-7$ & $\begin{array}{l}15.1 \%(9.1 \\
\text { to } 19.7 \%)\end{array}$ & $\begin{array}{l}\text { No differences in: sex } \\
\text { and NIHSS score. } \\
\text { Median age (IQR): } 72 \\
\text { (65-79) versus } 69 \text { (58- } \\
77) ;(p=0.001)\end{array}$ & IV tPA within $6 \mathrm{~h}$ & 10 & $\begin{array}{l}\text { ICH with } \\
\text { worsening of } \geq 4 \\
\text { points on NIHSS }\end{array}$ & - \\
\hline $\begin{array}{l}\text { Kim } \\
2006\end{array}$ & $\begin{array}{l}\text { Retrospective, } \\
\text { single centre }\end{array}$ & $65(57)$ & 67 & - & - & 30 & 5 & $\begin{array}{l}15.7 \%(8.1 \\
\text { to } 26.4 \%)\end{array}$ & $\begin{array}{l}\text { Hypertension and age } \\
\text { associated with CMBs } \\
(p<0.05)\end{array}$ & $\begin{array}{l}\text { IV tPA within } 3 \mathrm{~h} \\
(\mathrm{n}=12) ; \mathrm{IA} \text { UK } \\
\text { within } 6 \mathrm{~h} \\
(\mathrm{n}=53)\end{array}$ & $1-3$ & $\begin{array}{l}\text { Symptomatic } \\
\text { haemorrhage: } \\
\text { any neurological } \\
\text { deterioration } \\
\text { within the first } \\
48 \mathrm{~h} \text { that could } \\
\text { be attributed to } \\
\text { the presence } \\
\text { haemorrhage on } \\
\text { follow-up MRI }\end{array}$ & $\begin{array}{l}\text { Age, hypertension, } \\
\text { diabetes, atrial } \\
\text { fibrillation, stroke } \\
\text { history, smocking, } \\
\text { NIHSS score }\end{array}$ \\
\hline $\begin{array}{l}\text { Kakuda } \\
2005\end{array}$ & $\begin{array}{l}\text { Prospective, } \\
\text { multicentre (3) }\end{array}$ & $\begin{array}{l}70 \\
(44.3)\end{array}$ & 70.5 & $\begin{array}{l}11 \pm 9.2 / 13 \pm 9.8 \\
\mathrm{CMB}(+) /(-) \\
\text { (mean/SD) }\end{array}$ & 1.5 & $14-47$ & 5 & $\begin{array}{l}38.5 \%(26.7 \\
\text { to } 51.4 \%)\end{array}$ & $\begin{array}{l}\text { No differences in age, } \\
\text { time to treatment, blood } \\
\text { pressure, NIHSS, } \\
\text { hypertension. Diabetes, } \\
\text { dyslipidaemia, smoking }\end{array}$ & IV tPA within $6 \mathrm{~h}$ & 30 & $\begin{array}{l}\text { ICH with } \\
\text { worsening of } \geq 2 \\
\text { points on NIHSS }\end{array}$ & - \\
\hline $\begin{array}{l}\text { Derex } \\
2004\end{array}$ & $\begin{array}{l}\text { Retrospective, } \\
\text { single centre }\end{array}$ & $44(-)$ & $63.2+/-14.1$ & $\begin{array}{l}14 \pm 5.8 \text { (mean/ } \\
\text { SD) }\end{array}$ & 1.5 & 26 & 5 & $\begin{array}{l}18.2 \%(8.2 \\
\text { to } 32.7 \%)\end{array}$ & - & $\begin{array}{l}\text { IV tPA at two } \\
\text { different doses } \\
\text { within } 7 \mathrm{~h}\end{array}$ & 7 & $\begin{array}{l}\mathrm{ICH} \text { with } \\
\text { worsening of } \geq 4 \\
\text { points on NIHSS } \\
\text { or } \geq 1 \text { point on } \\
\text { NIHSS } \\
\text { consciousness } \\
\text { level }\end{array}$ & $\begin{array}{l}\text { Delay to treatment; } \\
\text { tPA dose }\end{array}$ \\
\hline $\begin{array}{l}\text { Kidwell } \\
2002\end{array}$ & $\begin{array}{l}\text { Retrospective, } \\
\text { single centre }\end{array}$ & $41(-)$ & - & - & 1.5 & 15 & 7 & $\begin{array}{l}12.2 \%(4.1 \\
\text { to } 26.2 \%)\end{array}$ & $\begin{array}{l}\text { No differences in age, } \\
\text { hypertension, diabetes, } \\
\text { hypercholesterolaemia, } \\
\text { smoking, and severity of } \\
\text { pretreatment } \\
\text { neurological deficit. }\end{array}$ & $\begin{array}{l}\text { IV/IA tPA within } \\
3 \mathrm{~h} \text {; IA UK or } \\
\text { tPA mechanical } \\
\text { clot disruption } \\
\text { during IA } \\
\text { thrombolysis }\end{array}$ & 7 & $\begin{array}{l}\text { ICH with } \\
\text { worsening of } \geq 4 \\
\text { points on NIHSS } \\
\text { or } \geq 1 \text { point on } \\
\text { NIHSS } \\
\text { consciousness } \\
\text { level }\end{array}$ & Thrombolysis regimen \\
\hline
\end{tabular}




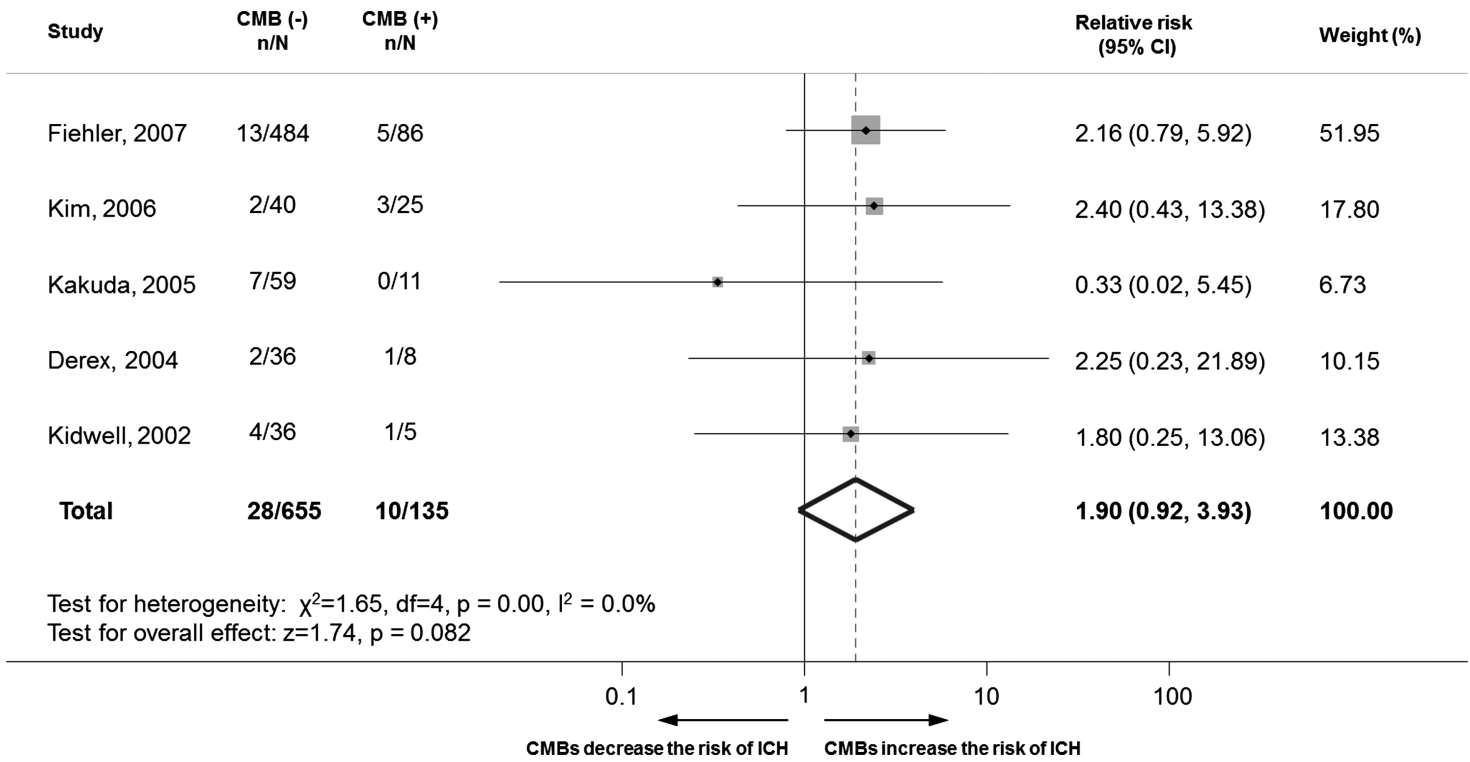

Figure 1 Meta-analysis of the association between intracerebral haemorrhage (ICH) risk in patients with acute ischaemic stroke treated with thrombolysis, in relation to the presence of cerebral microbleeds (CMBs) on pretreatment MRI scans. This figure is only reproduced in colour in the online version.

individuals with CMBs, particularly in view of the significant methodological limitations of included reports. Our data thus reinforce the need for further large multicentre studies (for suggested ideal study characteristics see online supplementary table S1) to evaluate whether the risk of ICH outweighs the benefit of thrombolysis in patients with CMBs, particularly those with multiple lobar CMBs suggestive of CAA. ${ }^{23}$

Contributors AC, PK, DJW: study concept and design; AC, PK: acquisition of data; AC, ZF, DJW: analysis and interpretation of data; AC, PK, DJW: drafting of the manuscript; $A C, P K$, ZF, DJW: critical revision of the manuscript for important intellectual content. ZF, AC: statistical analysis; DJW: study supervision.

Funding AC receives research support from the Greek State Scholarship Foundation, the British Heart Foundation and the Stroke Association; DJW receives research support from the Department of Health/Higher Education Funding Council for England (Clinical Senior Lectureship Award), the British Heart Foundation and the Stroke Association. Part of this work was undertaken at UCLH/UCL that received a proportion of funding from the Department of Health's National Institute for Health Research Biomedical Research Centre's funding scheme.

Competing interests None.

Provenance and peer review Not commissioned; externally peer reviewed.

Open Access This is an Open Access article distributed in accordance with the Creative Commons Attribution Non Commercial (CC BY-NC 3.0) license, which permits others to distribute, remix, adapt, build upon this work non-commercially, and license their derivative works on different terms, provided the original work is properly cited and the use is non-commercial. See: http://creativecommons.org/ licenses/by-nc/3.0/

\section{REFERENCES}

1. Derex L, Nighoghossian N. Intracerebral haemorrhage after thrombolysis for acute ischaemic stroke: an update. J Neurol Neurosurg Psychiatry 2008;79:1093-9.

2. Group Nr-PS. Tissue plasminogen activator for acute ischemic stroke. The National Institute of Neurological Disorders and Stroke rt-PA Stroke Study Group. N Engl J Med 1995:333:1581-7.

3. Fazekas $\mathbf{F}$, Kleinert R, Roob G, et al. Histopathologic analysis of foci of signal loss on gradient-echo $\mathrm{T}^{*}$-weighted MR images in patients with spontaneous intracerebral hemorrhage: evidence of microangiopathy-related microbleeds. AJNR Am J Neuroradiol 1999;20:637-42.

4. Charidimou A, Werring DJ. Cerebral microbleeds: detection, mechanisms and clinical challenges. Future Neurology 2011;6:587-611.

5. Kidwell CS, Saver JL, Villablanca JP, et al. Magnetic resonance imaging detection of microbleeds before thrombolysis: an emerging application. Stroke 2002;33:95-8.

6. Fiehler J, Albers GW, Boulanger JM, et al. Bleeding risk analysis in stroke imaging before thrombolysis (BRASIL): pooled analysis of $\mathrm{T} 2^{*}$-weighted magnetic resonance imaging data from 570 patients. Stroke 2007;38:2738-44.
7. Cordonnier C, Al-Shahi Salman R, Wardlaw J. Spontaneous brain microbleeds: systematic review, subgroup analyses and standards for study design and reporting. Brain 2007:130:1988-2003.

8. Stroup DF, Berlin JA, Morton SC, et al. Meta-analysis of observational studies in epidemiology: a proposal for reporting. Meta-analysis Of Observational Studies in Epidemiology (MOOSE) group. Jama 2000;283:2008-12.

9. Kim HS, Lee DH, Ryu CW, et al. Multiple cerebral microbleeds in hyperacute ischemic stroke: impact on prevalence and severity of early hemorrhagic transformation after thrombolytic treatment. AJR Am J Roentgenol 2006; 186:1443-9.

10. Kakuda W, Thijs VN, Lansberg MG, et al. Clinical importance of microbleeds in patients receiving IV thrombolysis. Neurology 2005;65:1175-8.

11. Derex L, Nighoghossian N, Hermier M, et al. Thrombolysis for ischemic stroke in patients with old microbleeds on pretreatment MRI. Cerebrovasc Dis 2004;17:238-41.

12. Fiehler J, Siemonsen $\mathrm{S}$, Thomalla $\mathrm{G}$, et al. Combination of $\mathrm{T} 2^{*} \mathrm{~W}$ and FLAIR abnormalities for the prediction of parenchymal hematoma following thrombolytic therapy in 100 stroke patients. J Neuroimaging 2009;19:311-16.

13. Soo Yo, Yang SR, Lam WW, et al. Risk vs benefit of anti-thrombotic therapy in ischaemic stroke patients with cerebral microbleeds. J Neurol 2008;255: 1679-86.

14. Lovelock CE, Cordonnier C, Naka H, et al. Antithrombotic drug use, cerebral microbleeds, and intracerebral hemorrhage: a systematic review of published and unpublished studies. Stroke 2010:41:1222-8.

15. Palumbo V, Boulanger JM, Hill MD, et al. Leukoaraiosis and intracerebral hemorrhage after thrombolysis in acute stroke. Neurology 2007;68: $1020-4$.

16. Neumann-Haefelin T, Hoelig S, Berkefeld J, et al. Leukoaraiosis is a risk factor for symptomatic intracerebral hemorrhage after thrombolysis for acute stroke. Stroke 2006;37:2463-6.

17. Gregoire SM, Werring DJ, Chaudhary UJ, et al. Choice of echo time on GRE $\mathrm{T} 22^{*}$-weighted MRI influences the classification of brain microbleeds. Clin Radiol 2010;65:391-4.

18. Jeon SB, Kwon SU, Cho AH, et al. Rapid appearance of new cerebral microbleeds after acute ischemic stroke. Neurology 2009;73:1638-44.

19. Ahmed N, Wahlgren N, Grond M, et al. Implementation and outcome of thrombolysis with alteplase $3-4.5 \mathrm{~h}$ after an acute stroke: an updated analysis from SITS-ISTR. Lancet Neurol 2010;9:866-74.

20. McCarron MO, Nicoll JA. Cerebral amyloid angiopathy and thrombolysis-related intracerebral haemorrhage. Lancet Neurol 2004;3:484-92.

21. Winkler DT, Biedermann L, Tolnay M, et al. Thrombolysis induces cerebral hemorrhage in a mouse model of cerebral amyloid angiopathy. Ann Neurol 2002:51:790-3.

22. Knudsen KA, Rosand J, Karluk D, et al. Clinical diagnosis of cerebral amyloid angiopathy: validation of the Boston criteria. Neurology 2001;56:537-9.

23. Charidimou A, Gang 0 , Werring DJ. Sporadic cerebral amyloid angiopathy revisited: recent insights into pathophysiology and clinical spectrum. J Neurol Neurosurg Psychiatry 2012;83:124-37. 